\title{
Institutions and Firm's Participation in the Global Production Network (GPN): Firm-Level Analysis in Indonesia
}

\author{
Eneng Herlin Herlina ${ }^{1}$, Toshihiro Kudo ${ }^{2}$ \\ ${ }^{1}$ Faculty of Economics and Business, Universitas Indonesia, Indonesia \\ ${ }^{2}$ Economics, Planning, and Public Policy Program, the National Graduate \\ Institute for Policy Studies (GRIPS), Japan \\ E-mail: herlina.enengherlin@yahoo.com
}

Received: October, 2019; Accepted: February, 2020; Published: March, 2020

Permalink/DOI: http://dx.doi.org/10.17977/um002v12i12020p026

\begin{abstract}
This paper argues that besides firm's internal factors, institutions may also affect a firm's participation in the production network. By analyzing the effect of access to credit, import license, and competition from the informal sector, this study attempts to provide an empirical study about institutions and firms' participation in the Global Production Network (GPN), study case in Indonesia. A logistic regression analysis shows that most variables are statistically significant, with some variations between larger firms and Small Medium Enterprises (SMEs). Access to credit, as an obstacle, negatively influences SMEs' participation, implying that SMEs in Indonesia are still constrained by financial institutions. Meanwhile, an import license can be regarded as the most crucial factor for the larger companies and SMEs, implying that it provides firms with more access to resources that may benefit their competitiveness. On the other hand, the informal sector tends to more negatively affect the larger firms than the SMEs, suggesting that its impact occurs through a specific channel. The findings highlight the influence of institutions on a firm's participation in the GPN and provide certain policy implications, i.e., financial development systems, signaling policies, simplifying procedures of granting import permits, and implementing a tax for the informal firms.
\end{abstract}

Keywords: Fragmentation, Institutions, Production Network JEL Classification: F12, F13, L60

\section{INTRODUCTION}

Globalization and international trade agreements result in fewer country barriers and fragmentation of production, allowing every country to boost its economy by engaging in the Global Production Network (GPN) and increasing its value-added in trade. The concept of GPN is based on the fragmentation theory proposed by Jones and Kierzkowski (1988) who argued that the production of goods can be spread to several countries and performed by several companies through production blocks and each company can specialize in one part of production based on the comparative advantage of its home country. Moreover, Baldwin (2016) stated that the combination of cheap resources and information, communication, and technology (ICT) might increase industrial competitiveness, 
enabling developed countries to move several stages of their production to the emerging economies.

However, the GPN comprises complex interactions with companies that are located across several countries and, thus, the role of an institution of a country becomes very important. According to North (1991), "Institutions are the humanly devised constraints that structure political, economic, and social interaction. They consist of both informal constraints (sanctions, taboos, customs, traditions, and codes of conduct) and formal rules (constitutions, laws, property rights)" (p.97). This study not only suggests that institutions play a role in determining various elements such as the economy, but it also highlights the importance of institutions - an aspect that might attract many scholars to analyze the relationship between institutions and economic development. According to Acemoglu, Johnson, and Robinson (2004), institutions play an important role in facilitating economic development. Empirically, property right institutions affect long-run economic growth, investment, and financial development (Acemoglu \& Johnson, 2005). Similarly, Dollar and Kraay (2003) stated that countries that are more developed have relatively better institutions and trading performance. Levchenko (2007) discovered that the distinction between institutions across countries affects a country's trade flows. In the manufacturing sector, Méon and Sekkat (2008) found that the quality of institutions is positively associated with the export ratio of this sector, particularly, an improvement in the quality of the regulatory framework. All these studies suggest that to improve the economy of a country, the government needs to provide a better quality of institutions.

Table 1. Ease of Doing Business Ranking 2011-2016

\begin{tabular}{|c|c|c|c|c|c|c|}
\hline Economy & 2011 & 2012 & 2013 & 2014 & 2015 & 2016 \\
\hline Singapore & 1 & 1 & 1 & 1 & 1 & 1 \\
\hline Malaysia & 23 & 18 & 12 & 6 & 18 & 18 \\
\hline Thailand & 16 & 17 & 18 & 18 & 26 & 49 \\
\hline Vietnam & 90 & 98 & 99 & 99 & 78 & 90 \\
\hline Indonesia & 126 & 129 & 128 & 120 & 114 & 109 \\
\hline Philippines & 134 & 136 & 138 & 108 & 95 & 103 \\
\hline
\end{tabular}

Source: Author's compilation using data from Doing Business 2012, Doing Business 2013, Doing Business 2014, Doing Business 2015, and Doing Business 2016 of The International Bank for Reconstruction and Development/The World Bank, 2019.

The quality of institutions of a country may be indicated by a ranking of ease of doing business provided by the World Bank in Table 1. According to this ranking, from 2011 to 2016, Indonesia was left behind compared to other Southeast-Asian countries. Indonesia ranked 126th in 2011 and 129th in 2012 before rising to 128th in 2013; Indonesia was ranked below Singapore, Malaysia, Thailand, and Vietnam. After that, although Indonesia's ranking from 2014 to 2016 gradually improved, its position in the Southeast-Asian region has been displaced by the Philippines. Thus, Indonesia was ranked sixth during this period. This ranking suggests that Indonesia needs to improve the quality of its institutions to provide a favorable business environment for companies. 
Furthermore, this ranking implies that firms may still encounter many difficulties while conducting business in Indonesia-difficulties that may inhibit the firms from producing a higher value-added product for the country.

Figure 1 shows a fluctuation in the growth of domestic value-added productions in Indonesia from 2006 to 2016. The growth declined from $20 \%$ to $0 \%$ between 2006 and 2016. The most significant decline occurred after the global financial crisis where the growth of domestic value-added decreased negatively by up to $10 \%$ in 2009 before it began to rise. On the other hand, the highest growth was recorded in 2010, reaching a peak of 35\%. Nevertheless, it dropped substantially from 2011 to 2015 before it reversed its course in 2016. Although other countries experienced the same condition, the figure illustrates that Indonesia has undergone significant changes. These changes are not only influenced by international conditions, such as the financial crisis in 2008, but also by other factors, for example, the country's condition and firm's capability.

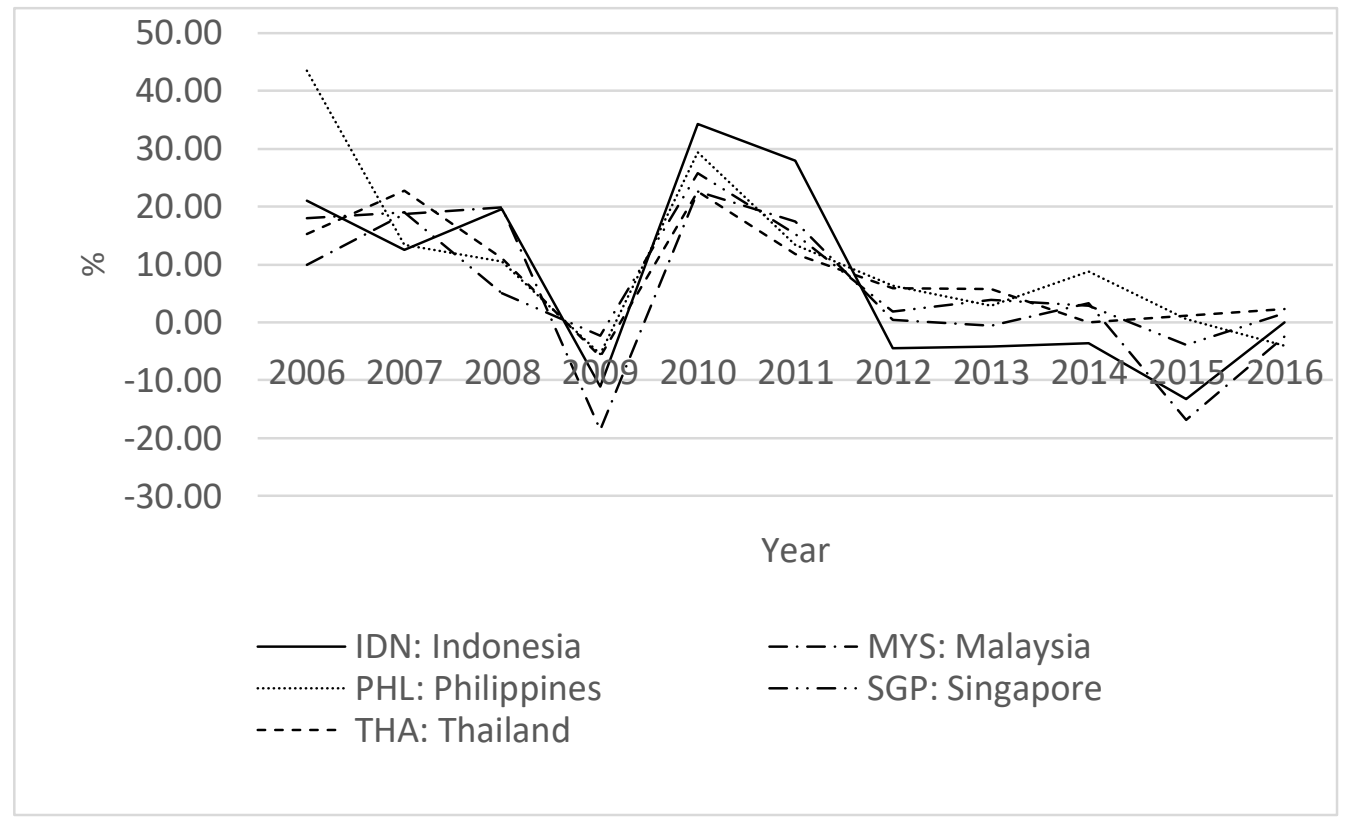

Figure 1. Growth of Domestic Value-Added Content of Gross Exports.

Source: Author's calculation using data from Organisation for Economic Co-operation and Development (OECD), 2019.

With respect to a firm-level analysis of production network participation in Southeast-Asian countries, including Indonesia, many studies only focus on a firm's characteristics (Harvie, Narjoko, \& Oum, 2010; Rasiah, Roesli, \& Sanjivee, 2010; Wignaraja, 2015; Arudchelvan \& Wignaraja, 2015) based on the concept of firm heterogeneity proposed by Melitz (2003). Only a few studies aim to analyze institutions and firm's participation (Dollar, Ge, \& Yu, 2016, as cited in Dollar \& Kidder, 2017). It should be noted that participation in a production network may not only be restricted by the internal factors of a firm such as the firm's characteristics but also external factors, such as institutions of a country. Institutions are needed in the GPN because they may contribute to solving problems in the network and determining the competitiveness of a country. According to Dollar and Kidder (2017), goods that have complex value chains involve many exchanges between companies and might create a risk of contract 
nonperformance from other firms; thus, better institutions, such as better enforcement of property rights and a rule of law, are needed to resolve this problem. Moreover, this paper argues that comparative advantage not on depends on increasing the productivity of a country, as explained by the Ricardian theory, but also on the role of institutions. Institutions might reduce or exacerbate distortions arising from asymmetrical information that may emerge in the production network. Furthermore, this paper highlights the role of financial institutions as a pivotal factor in deepening participation. This study suggests that institutions influence many aspects of production and, thus, it is necessary to improve the quality of institutions to resolve unfavorable situations that may arise in the production network. Therefore, institutions may determine participation in the network.

Appropriate government policies to encourage a firm's engagement in the GPN serve as an indicator of good institutions. According to Prete, Giovannetti, and Marvasi (2018), participation in the global value chain (GVC) depends on local conditions. These authors argued that a production network requires effective and efficient coordination among various production stages and, thus, favorable government policies aimed at facilitating finance and trade, establishing regulation, and improving infrastructure become important. In other words, these authors imply that proper governmental policies are essential in the production network. Similarly, Abonyi and Van Slyke (2010) argued that to provide effective policies, strengthening institutions should be a fundamental step in public administration reform. This study suggests that when institutions are well established, the government can create suitable policies to support firms in the production network. In summary, the aforementioned studies suggest that government support through several mechanisms is essential in the GPN, as this support promotes a firm's participation in the production network, indicating the good quality of institutions in a country. However, if policies seem to hinder companies from conducting business, a firm may be reluctant to engage in the production network, indicating poor functioning of institutions. Therefore, institutions play a significant role in the GPN.

Several studies have described access to credit as an indicator of the quality of financial institutions. In particular, countries with more advanced financial systems report lower funding barriers (Beck, Demirgüç-Kunt, \& Maksimovic, 2005). Furthermore, companies located in countries with better financial systems in terms of access to credit tend to export more than countries that face barriers to access to credit. Thus, the characteristics of financial institutions play a role in determining the trade value of a country (Goksel, 2012). This study suggests that when financial institutions are more developed, companies face fewer barriers to accessing credit. Additionally, more accessible credit increases a company's export decisions, as the company may be better able to cover export costs.

In the production network analysis, access to credit determines a firm's decision to participate in a production network. Wignaraja (2015) provided evidence to suggest that the availability of access to credit positively affects a firm's participation in a production network. Furthermore, he deduced that access to credit determines the sustainability of export in a production network. In line with this, Dollar et al. (2016, as cited in Dollar \& Kidder, 2017) found that apart 
from fewer government interventions, better contract enforcement and customs efficiency, more accessible credit increases the likelihood of companies to enter the GVC. However, firms may encounter various obstacles in accessing credit, which might affect their development. Examining financial constraints, Beck et al. (2005) found that these constraints inhibit a firm's growth. Other studies discovered that credit constraints act as trade barriers, impeding a firm's performance and resulting in low trade value (Goksel, 2012). Similarly, Manova (2012), as well as Minetti and Zhu (2011) showed that credit constraints act as an obstacle to export and negatively affect foreign sales, especially for high-tech industries firms and for industries that are very dependent on external finance (Minetti \& Zhu, 2011). Moreover, Lu, Shi, Luo, and Liu (2018) found that financial constraints have a significant negative impact on the firm's participation in a production network. These findings imply that access to credit can be regarded as a crucial issue, as limited access to credit may hinder a firm from procuring additional capital, thereby negatively affecting their involvement in the GPN.

Beside financial institutions, other institutional aspect of this study is that trade facilitation which can be defined as various policies related to the movement of goods aimed at reducing transaction costs, especially in customs procedures. However, concerning procedures related to trade, obtaining import licenses is considered to be one of the most problematic issues in Indonesia (Damuri, 2006). This implies that trade procedures in Indonesia in terms of import license have not gone well, which may be attributed to inefficient procedures or the possibility of rent-seeking behavior. Similarly, Krueger (1990) argued that quantitative restrictions on import licenses tend to result in more rent-seeking behavior. Better trade facilitation may be achieved by reducing transaction costs, which can be accomplished by implementing efficient and effective procedures, particularly in the process of obtaining an import license. Moreover, better trade facilitation may reflect better quality of institutions.

Several studies have emphasized that imported input of production is vital for a firm's performance. First, Dick (1994) discovered that import protection by the U.S. cannot drive domestic output, leading to inefficiency in a firm's scale and deterrence in export market share. Additionally, Muûls and Pisu (2009) found that a firm's productivity increases with an increase in the number of imported products. Furthermore, Bhaduri and Ray (2004) showed that a more considerable imported raw materials affects the export performance of the pharmaceutical industry in India. They argued that access to imported raw materials helps the industry become more competitive both in terms of price and quality. These studies suggest that providing access to imported materials is not only essential to stimulate a firm's productivity but also to promote export performances. Import licenses as a means of trade facilitation (Damuri, 2006) may provide alternative resources to a firm in terms of input of production. It allows a firm to have more access to various resources, comprising cheap raw materials or even high-quality input production, which may increase the competitiveness of local firms. Thus, an import license may positively determine GPN participation.

There is growing literature with respect to the analysis of institutions and informality. Dell'Anno (2009) examined the informal sector by associating it with inadequate rules of law and lack of regulation. However, Johnson, Kaufmann, and 
Zoido-Lobatón (1998) discovered that excessive regulations result in an increase in informal sectors, as more regulations entail more political control by the elite, leading to regulatory discretion. They found that bureaucratic quality, the way regulations are implemented, is significantly correlated to this unofficial economy. Specifically, Johnson et al. (1998) showed that a higher bureaucratic quality reduces the share of informal sectors. Moreover, a stronger rule of law, a better legal system, and more security of property right lower informality while corruption increases this informal sector. This study illustrates that institutional quality is more important than the quantity of regulation, as the quality of institutions reflects how formal rules are enforced. Good-quality institutions are indicated by effective and efficient enforcement of rules. Low-quality institutions, on the other hand, lead to several problems, for example, in this case, an informal sector.

In the parasitic view of informality, informal sectors may adversely affect the formal one. These effects are not necessarily related to an increase in competition; they can be influenced by other mechanisms as well. Farell (2004) argued that the widespread informal sector not only impedes economic growth but also results in reduced government tax revenue, which indirectly leads to an increase in tax in the formal sector. Moreover, informal firms may have an adverse selection effect on the formal one in terms of accessing credit from financial institutions. Distinguin, Rugemintwari, and Tacneng (2016) showed that SMEs that face competition from informal sectors are more likely to be affected by credit constraints, particularly, the smaller firms, as they have similar characteristics as the informal sector. Furthermore, informal competition may negatively affect a formal firm's innovation due to the possibility of being imitated (Mendi \& Costamagna, 2017; Pérez et al., 2018). Based on these studies, it seems that the impact of competition from the informal sector works via several channels, which may negatively influence a firm's participation in the GPN.

For a comprehensive analysis, this study uses various characteristics of a firm as a variable control to analyze a firm's participation in the GPN. First, firm age can be regarded as a fundamental factor in analyzing a firm's behavior; this factor is employed by several scholars to assess trade (Andersson, Gabrielsson, \& Wictor, 2009; Baldauf, Cravens, \& Wagner, 2000; Javalgi, White, \& Lee, 2000; Van Dijk, 2002) and production network (Wignaraja, 2015). Second, firm size is used to determine the probability of export (Javalgi et al., 2000; Wagner, 2001; Van Dijk, 2002), export sales (Baldauf et al., 2000; Minetti \& Zhu, 2011), export intensity (Baldauf et al., 2000; Majocchi, Bacchiocchi, \& Mayrhofer, 2005; Wagner, 2001), and the likelihood of participation in a production network (Arudchelvan \& Wignaraja, 2015; Harvie et al., 2010; Rasiah et al., 2010; Wignaraja, 2015). Third, foreign ownership influences a firm's success in exporting activity (Bhaduri \& Ray, 2004; Van Dijk, 2002) and encourages local firms to participate in the production network (Harvie et al., 2010; Wignaraja, 2015). Lastly, human capital may influence a firm's productivity (Haltiwanger, Lane, \& Spletzer, 1999), firm's decision to export (Van Djik, 2002), firm's participation in the production network (Wignaraja, 2015), as well as export sales (Minetti \& Zhu, 2011).

Other factors that are used in this study to analyze a firm's participation in the GPN have been listed as follows: international quality certification (IQC), 
foreign technology license, and innovation, which represent technological capabilities. Some studies have found that IQC not only affects export participation but also the export scale (Goedhuys \& Sleuwaegen, 2013). Furthermore, it increases productivity and sales performance via efficiency gains and quality signaling (Goedhuys \& Sleuwaegen, 2013); therefore, it might increase the probability of the firm to participate in the production network (Wignaraja, 2015). For the foreign technology license factor, several studies have found that it affects a firm's participation in the production network (Arudchelvan \& Wignaraja, 2015; Wignaraja, 2015). Innovation, on the other hand, is closely associated with export activity; for example, the likelihood to export (Wakelin, 1998), export sales (Singh, 2009), and export intensity (Pla-Barber, \& Alegre, 2007; D'Angelo, 2010) which might be caused by the increase in productivity (Coad, Segarra, \& Teruel, 2016). In the production network, Harvie et al. (2010) found that both process and product innovation efforts are important factors in determining a firm's participation and upgrading position.

\section{METHOD}

Similar to the studies of Wignaraja (2015) and Dollar et al. (2016, as cited in Dollar \& Kidder, 2017), the data for this study is also obtained from the World Bank, specifically from the Enterprises Surveys (ES). The objective of the surveys is to collect data about firms' experiences in the private sector. Besides, the World Bank has promoted the improvement of the business environment as the primary strategy for development. Thus, the surveys are a project in gathering both data on companies' experiences and their perceptions about the business environment. This study applies cross-sectional data and uses recently collected data from the 2015 Indonesia Enterprise Survey, which examined a total of 1,320 firms. These firms can be classified into three industries, namely, manufacturing, retail, and other services. However, this study only focuses on manufacturing firms in Indonesia. After excluding the retail and other services' industries, the total number of manufacturing firms about which data is available becomes 1,074, comprising 356 large firms and 718 SMEs.

There are several measurements to define production network participation. Wignaraja (2015) used a probit model and classified supply chain participation in terms of whether a firm exports its product directly and/or indirectly. Dollar et al. (2016, as cited in Dollar \& Kidder, 2017), however, used a multinomial logit model for their study; this model consists of four categories: firm uses domestic input for the domestic market, the firm uses domestic input for export, the firm uses foreign input for domestic consumption, and the firm uses foreign input for exporting activity. Harvie et al. (2010) defined production network participation as a firm's involvement as a supplier or subcontractor, importing intermediate input, or exporting some of its products. The ES World Bank provided information about a firm's sales destination, namely, national sales, direct export, indirect export, or sales to a third party. According to Wignaraja (2015), the indirect sale is an indicator of a firm acting as a supplier, and he used direct and indirect export as the indicator of firm's participation in the production network. This study follows the same approach by Wignaraja (2015) to measure production network participation. In other words, GPN participation will be determined depending on whether a firm export directly and/or indirectly. 
This study analyzes the probability of firms to participate in the GPN as the dependent variable. For this purpose, it uses a binary model, considering the value of 1 if a firm is found to participate in the GPN or 0 if not. According to Bewick, Cheek, and Ball (2005), logistic regression well accompanies a binary model with one or more explanatory variables which can be continuous or categorical. Therefore, this study will employ a quantitative method using logistic regression analysis.

Three variables represent institutional aspects, namely, access to credit, import license, and competitors from the informal sector. This study uses a dummy variable for import license while a firm's perceptions are used to measure access to credit and competition from the informal sector. Based on the ES, the perceptions about access to credit and practices of competitors from the informal sector are measured using a five-point Likert scale with values between 0 and 4 , with 0 indicating no obstacles, 1 a minor obstacle, 2 a moderate obstacle, 3 a major obstacle, and 4 denoting a very severe obstacle.

Apart from analyzing an institution's variables, this study employs several variables from Wignaraja's (2015) study, namely, firm age, firm size, foreign ownership, human capital, and technological capabilities, which are indicated by IQC and a technology license from a foreign company. Furthermore, this study uses innovation as an additional variable to assess a firm's technological capability. For foreign ownership, this study uses a percentage value to reflect the degree of ownership. The regression is estimated as follows:

$$
\begin{aligned}
\text { GPNPart }_{i}=\alpha_{0}+\beta_{1} \text { AccesstoCredit }+\beta_{2} \text { ImportLicense }_{i}+ \\
\\
\beta_{3} \text { Competitorsfromtheinformalsector }_{i}+\beta_{4} \text { Age }_{i}+\beta_{5} \text { Size }_{i}+ \\
\beta_{6} \text { ForeignOnwership }_{i}+\beta_{7} \text { Human Capital }_{i}+\beta_{8} I_{Q} C_{i}+ \\
\beta_{9} \text { TechnologyLicense }_{i}+\beta_{10} \text { Innovation }_{i}++\varepsilon_{i} \ldots \ldots \ldots \ldots \ldots \ldots \ldots
\end{aligned}
$$

In the equation (1), GPNPart denotes GPN participation, which uses a binary value, taking 1 if the firm exports directly or indirectly (sells its product to a third party) and 0 if a firm is wholly domestically market-oriented (Wignaraja, 2015). Access to credit is measured by a firm's perceptions and categorized from 0 to 4 where 0 indicates no obstacle, 1 a minor obstacle, 2 a moderate obstacle, 3 a major obstacle, and 4 a very severe obstacle. Import license is indicated by a dummy variable, which is 1 if a firm applies to obtain an import license and 0 if not. Competitorsfromtheinformalsector, pertaining to practices of competitors in the informal sector, is measured based on a firm's perceptions and categorized from 0 to 4 where 0 indicates no obstacle, 1 a minor obstacle, 2 a moderate obstacle, 3 a major obstacle, and 4 a very severe obstacle. Age is measured by the number of years a firm has been operating while Size is defined by the number of employees. Foreign ownership is measured based on the percentage of a firm that is owned by private foreign individuals, companies or organizations. Human capital is represented by a dummy variable, which is 1 if the average production worker has a high school education (more than 6 years of education) and 0 if otherwise. $I Q C$ is denoted by a dummy variable, which is 1 if the firm has IQC and 0 if otherwise. Technology license is also represented by a dummy variable, which is 1 if the firm has a technology license and 0 if otherwise. Innovation is represented by a dummy variable, which is 1 if the firm 
introduces new or significantly improved products and 0 if not, $\varepsilon$ is for error term, and $i$ denotes a firm -1 for the first firm, and so on.

\section{RESULTS AND DISCUSSION}

Table 2 summarizes the statistics of the data after clearly defining and setting the variables. Data was collected about 1,074 companies, with SMEs comprising approximately $70 \%$ of the total. GPN participation is a binary variable, which is value 1 if the firm participates in the GPN and 0 if not. The mean value of this variable shows that SMEs tend to participate less in the GPN. The import license variable is measured by a dummy variable and indicates that SMEs are less likely to apply for an import license. The access to credit and competitors from the informal sector variables are measured using a five-point Likert scale, ranging from 0 to 4 , with 0 indicating no obstacle and 4 a very severe obstacle. Meanwhile, the mean value of both variables shows that both SMEs and larger firms perceive access to credit and practices of competitors in the informal sector as a minor to a moderate obstacle. With respect to firm age, the youngest firm among both larger firms and SMEs was found to be two years old while the oldest firm among SMEs was found to be 95 years old, and the oldest firm among the larger firms was found to be 59 years old. For firm size, the smallest firm was found to be an SME with two employees while the biggest was found to be a larger firm with 7,000 employees. The measurements of foreign ownership varied from $0 \%$, indicating the absence of foreign ownership, to $100 \%$, indicating full foreign ownership; these measurements were applicable to both larger firms and SMEs. The average production worker in large firms and SMEs tends to have a high-school education with more than six years of education. Lastly, large firms are more likely to have an IQC and a technology license, and they are more likely to initiate innovation.

Table 2. Summary of Statistics

\begin{tabular}{llrrrrr}
\hline \multicolumn{1}{c}{ Variables } & Obs. & Mean & $\begin{array}{c}\text { Std. } \\
\text { Dev. }\end{array}$ & Min. & Max. \\
\hline $\begin{array}{llrrrl}\text { Dependent Variable } \\
\text { GPN Participation }\end{array}$ & Total Firms & 1,074 & 0.19181 & 0.39391 & 0 & 1 \\
& Large Firms & 344 & 0.427326 & 0.495411 & 0 & 1 \\
& SMEs & 730 & 0.080822 & 0.272748 & 0 & 1 \\
Institution Variables & & & & & & \\
Access to Credit & Total Firms & 1,067 & 1.22118 & 1.24329 & 0 & 4 \\
& Large Firms & 344 & 1.311047 & 1.297809 & 0 & 4 \\
& SMEs & 723 & 1.178423 & 1.215085 & 0 & 4 \\
Import License & Total Firms & 1,071 & 0.08684 & 0.28172 & 0 & 1 \\
& Large Firms & 343 & 0.247813 & 0.432374 & 0 & 1 \\
& SMEs & 728 & 0.010989 & 0.104323 & 0 & 1 \\
Competitors from & Total Firms & 1,057 & 1.48439 & 1.22937 & 0 & 4 \\
the informal sector & Large Firms & 337 & 1.522255 & 1.258404 & 0 & 4 \\
& SMEs & 720 & 1.466667 & 1.216026 & 0 & 4
\end{tabular}

Control Variables 


\begin{tabular}{|c|c|c|c|c|c|c|}
\hline \multicolumn{7}{|c|}{ Firm's Characteristics } \\
\hline \multirow[t]{3}{*}{ Age } & Total Firms & 1,071 & 21.1074 & 11.1904 & 2 & 95 \\
\hline & Large Firms & 342 & 25.78655 & 11.41248 & 2 & 59 \\
\hline & SMEs & 729 & 18.91221 & 10.38916 & 2 & 95 \\
\hline \multirow[t]{3}{*}{ Size } & Total Firms & 1,074 & 162.629 & 450.024 & 2 & 7000 \\
\hline & Large Firms & 344 & 448.7994 & 715.09 & 100 & 7000 \\
\hline & SMEs & 730 & 27.77671 & 25.26205 & 2 & 99 \\
\hline \multirow[t]{3}{*}{ Foreign Ownership } & Total Firms & 1,074 & 4.82775 & 16.4572 & 0 & 100 \\
\hline & Large Firms & 344 & 12.11628 & 23.35212 & 0 & 100 \\
\hline & SMEs & 730 & 1.393151 & 10.25599 & 0 & 100 \\
\hline \multirow[t]{3}{*}{ Human Capital } & Total Firms & 1,003 & 0.9332 & 0.2498 & 0 & 1 \\
\hline & Large Firms & 326 & 0.972393 & 0.164097 & 0 & 1 \\
\hline & SMEs & 677 & 0.914328 & 0.280086 & 0 & 1 \\
\hline \multicolumn{7}{|c|}{ Technological Capabilities } \\
\hline \multirow[t]{3}{*}{ IQC } & Total Firms & 1,066 & 0.22889 & 0.42032 & 0 & 1 \\
\hline & Large Firms & 341 & 0.557185 & 0.497449 & 0 & 1 \\
\hline & SMEs & 725 & 0.074483 & 0.262736 & 0 & 1 \\
\hline \multirow[t]{3}{*}{ Technology License } & Total Firms & 1,051 & 0.27878 & 0.44861 & 0 & 1 \\
\hline & Large Firms & 340 & 0.511765 & 0.500598 & 0 & 1 \\
\hline & SMEs & 711 & 0.16737 & 0.373569 & 0 & 1 \\
\hline \multirow[t]{3}{*}{ Innovation } & Total Firms & 1,068 & 0.12641 & 0.33246 & 0 & 1 \\
\hline & Large Firms & 338 & 0.204142 & 0.403671 & 0 & 1 \\
\hline & SMEs & 730 & 0.090411 & 0.286966 & 0 & 1 \\
\hline
\end{tabular}

Source: Author's calculation, 2019.

Table 3 shows how GPN participation is influenced by several factors, such as institutions and other characteristics. The above table provides three results/observations for the total number of firms, large firms, and SMEs. In each scale of the firm, two results comprise a coefficient and an odds ratio. The coefficient shows the direction of the relationship between explanatory variables and the dependent variable, while the odds ratio explains the magnitude of this relationship.

Table 2. GPN Participation

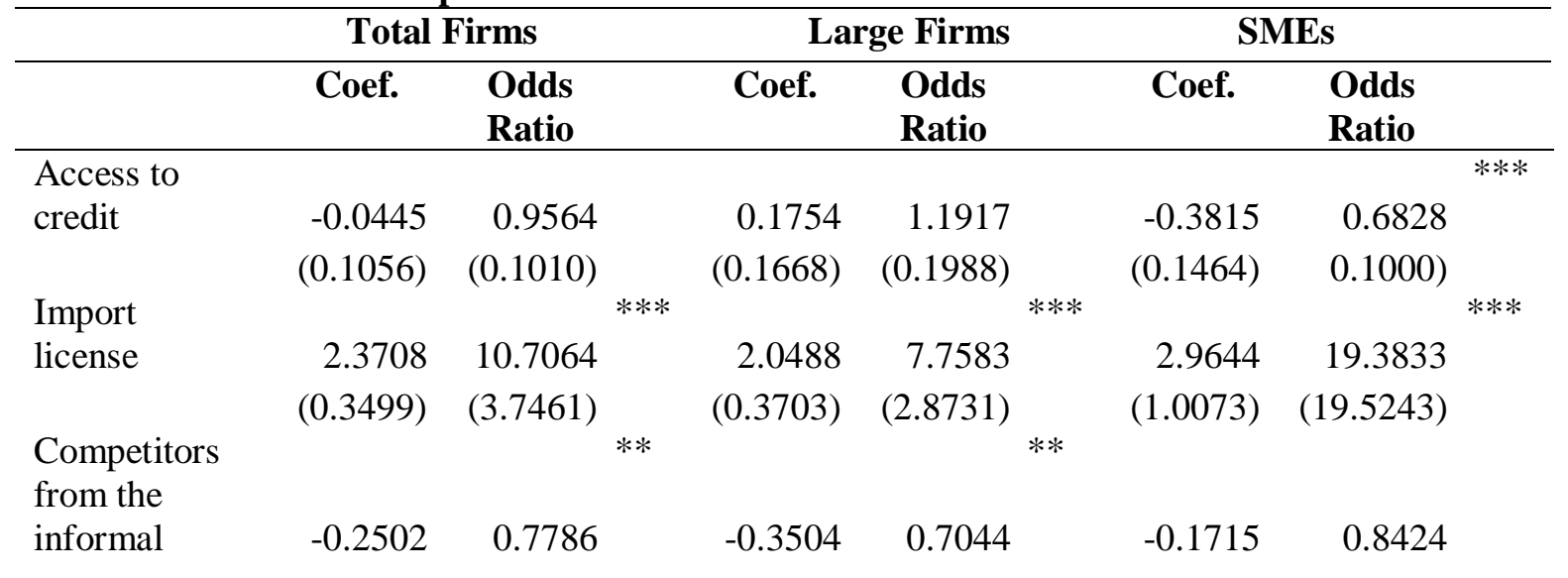


sector

\begin{tabular}{|c|c|c|c|c|c|c|c|c|}
\hline & $(0.1136)$ & $(0.0884)$ & & $(0.1726)$ & $(0.1216)$ & $(0.1643)$ & $(0.1384)$ & \\
\hline \multirow[t]{2}{*}{ Age } & 0.0267 & 1.0270 & $* * *$ & 0.0049 & 1.0049 & 0.0375 & 1.0382 & $* * *$ \\
\hline & $(0.0091)$ & $(0.0094)$ & & $(0.0129)$ & $(0.0129)$ & $(0.0126)$ & $(0.0131)$ & \\
\hline \multirow[t]{2}{*}{ Size } & 0.0006 & 1.0006 & $* *$ & 0.0003 & 1.0003 & 0.0132 & 1.0132 & $* *$ \\
\hline & $(0.0002)$ & $(0.0002)$ & & $(0.0002)$ & $(0.0002)$ & $(0.0063)$ & $(0.0064)$ & \\
\hline Foreign & & & $* * *$ & & $* * *$ & & & $* * *$ \\
\hline \multirow[t]{2}{*}{ Ownership } & 1.1696 & 1.0238 & & 0.0197 & 1.0199 & 0.0278 & 1.0282 & \\
\hline & $(0.2497)$ & $(0.0056)$ & & $(0.0067)$ & $(0.0068)$ & $(0.0083)$ & $(0.0085)$ & \\
\hline Human & & & $* *$ & & & & & $*$ \\
\hline \multirow[t]{2}{*}{ Capital } & 0.6804 & 5.0527 & & 1.5380 & 4.6555 & 1.7903 & 5.9912 & \\
\hline & $(0.2411)$ & (4.1647) & & $(1.5022)$ & (6.9937) & $(0.9164)$ & $(5.4905)$ & \\
\hline \multirow[t]{2}{*}{ IQC } & 0.0235 & 3.2209 & $* * *$ & 1.1144 & $3.0479 * * *$ & 0.1546 & 1.1672 & \\
\hline & $(0.0054)$ & $(0.8044)$ & & $(0.3272)$ & $(0.9972)$ & $(0.5124)$ & $(0.5981)$ & \\
\hline Technology & & & $* * *$ & & & & & $* *$ \\
\hline \multirow[t]{2}{*}{ License } & 1.6199 & 1.9747 & & 0.4859 & 1.6257 & 0.8532 & 2.3472 & \\
\hline & $(0.8243)$ & $(0.4760)$ & & $(0.2968)$ & $(0.4825)$ & $(0.4124)$ & $(0.9680)$ & \\
\hline \multirow[t]{2}{*}{ Innovation } & 0.9406 & 2.5615 & $* * *$ & 1.1498 & 3.1576 *** & 0.7573 & 2.1326 & \\
\hline & $(0.2954)$ & $(0.7567)$ & & $(0.3962)$ & (1.2509) & $(0.4794)$ & (1.0224) & \\
\hline Pseudo R2 & \multicolumn{3}{|c|}{0.3715} & \multicolumn{2}{|c|}{0.3151} & \multicolumn{3}{|c|}{0.1971} \\
\hline Obs. & \multicolumn{3}{|c|}{967} & \multicolumn{2}{|r|}{310} & \multicolumn{3}{|c|}{657} \\
\hline
\end{tabular}

Surprisingly, access to credit as an obstacle appears to only negatively affect SMEs' participation while in the total firm model, access to credit has no statistically significant impact on a firm's participation, even though this coefficient corresponds to the hypothesis, and in the case of large firms, the coefficient is positive but not significant. The odds ratio shows that when a firm's perception about access to credit as an obstacle increases, it indicates that the odds of engaging in the network will be 0.6828 times lower. A plausible reason is that exporting requires high costs and sufficient capital to cover entry and other trade costs (Manova, 2012). Meanwhile, limited access to credit may prevent SMEs from taking a loan to pay the costs and increase their capital to expand their business. Therefore, the probability of SMEs to participate in the GPN decreases. This result is consistent with that of previous studies' where credit constraints act as trade barrier (Goksel, 2012) to export and reduce both a firm's foreign sales and their likelihood to export (Manova, 2012; Minetti \& Zhu, 2011).

The findings of this study suggest that, unlike bigger companies that may have more resources, SMEs still perceive access to credit in Indonesia as a prominent constraint. A plausible reason is that SMEs are the most affected by financial constraints (Beck et al., 2005) and credit rationing (Minetti \& Zhu, 2011). Using 161 samples from three industry sectors (clothing and garment, parts and components of automobiles, and parts and components of electronics and machinery), Machmud and Huda (2011) showed that apart from insufficient collaterals and the lack of SMEs' ability to make appropriate business plans for credit applications, high transaction costs and the perceptions of financial 
institutions that SMEs are less capable of repaying the loans are the reason half of SMEs in Indonesia have no access to credit. This study suggests that barriers for SMEs in accessing credit are not only caused by the inability of SMEs to make themselves more bankable but also because of the tendency of financial institutions to be complicated. Beck et al. (2005), as well Dong and Men (2014) concluded that the development of financial systems, particularly the development of the banking sector, might improve the financing of SMEs and reduce financing obstacles and constraints encountered by them. Therefore, to support the firm's participation in the GPN, financial development may be regarded as an essential step.

An import license is positively associated with a firm's participation in the GPN; thus, this result is consistent with the hypothesis. The odds of participating are 10.7064 times higher than a firm who does not apply for an import license. Moreover, the magnitude of the odds ratio is the highest among the other factors, indicating that import licenses may be the most crucial factor for both larger firms and SMEs. A plausible reason is that firms may realize that import licenses can allow them to access more resources and better-quality resources for the input of production. Furthermore, a better quality of input of production may produce a better product and increase the competitiveness of local firms (Bhaduri \& Ray, 2004); hence, their probability of participation increases. Another interesting finding is that SMEs tend to participate more than the larger firms, as seen from the magnitude of the odds ratio of SMEs, which is higher than that of the larger firms'. The reason may be related to the characteristics of SMEs. SMEs lack resources, given the high prices of limited resources in Indonesia, and they have a low ability to compete with large companies in purchasing these resources. Access to foreign input through import licenses may be an alternative for SMEs to obtain both cheaper and a higher quality of input production.

The significant result obtained for the import license factor may drive government policy; for example, the results may aid in creating effective and efficient procedures in the process of granting import permits. Better procedures may encourage more firms to apply for an import license and stimulate them to be more involved in the production network. Moreover, simplifying procedures and making them more transparent can be regarded as a form of institutional reform, which may reduce transaction costs and eliminate the possibility of rent-seeking. According to North (1991), "institutions reduce transaction and production costs per exchange so that the potential gains from trade are realizable" (p. 98); therefore, to take more advantages in trade activity, implementing better institutions becomes necessary.

Practices of competitors in the informal sectors reduce the probability of firms participating in the GPN; thus, this finding supports the hypothesis. The odds ratio shows that if a firm's perception about practices of competition from the informal sector as an obstacle increase, their odds of participating in the network will be 0.7786 times lower. However, the results differ between large firms and SMEs. The coefficient is negative in both cases, but the impact of informal competition on participation in the GPN can only be observed among larger firms. This impact may arise through specific channels, as Farell (2004) stated; for example, an increase in tax rates for the formal sector. This effect may disadvantage the larger firms, especially the exporter firms because higher tax 
means a higher cost. Therefore, their tendency to participate in the GPN decreases. On the other hand, in the SMEs' model, informal competition cannot be regarded as the main obstacle because of its insignificant results. One plausible reason could be related to the characteristics of SMEs, which are relatively similar to that of the informal sectors'.

Previous studies have shown that the informal sector is closely related to the quality of institutions (Dell'Anno, 2009; Johnson et al., 1998); thus, an improvement in institutions may reduce the effects of the informal sector. According to Distinguin et al. (2016), the impact of informal competition is less severe for firms operating in a country with a better quality of institutions. In a country that prevents corruption and has a better rule of law and business regulatory environment, a formal firm experiences less impact from the competition of the informal sector. Similarly, Johnson et al. (1998) showed that a higher quality of institutions drops the number of this sector. In contrast, Distinguin et al. (2016) stressed that the poor quality of institution increases the size of an informal economy due to an increase in costs and lower benefits for formal firms. Furthermore, Friedman, Johnson, Kaufmann, and Zoido-Lobaton (2000) stated that an increase in the informal sector leads to lower tax revenue, which affects the quality of public administration. These studies suggest the importance of quality improvement in institutions in creating either a favorable business environment for the a or a higher country revenue. Therefore, improving institutional quality is an important issue for policymakers.

Older firms are more likely to engage in the GPN. This result is not consistent with the previous studies (Wignaraja, 2015; Lu et al., 2018). One possible explanation is that compared to newer firms, older firms may have dynamic capabilities (Sapienza, Autio, George, \& Zahra, 2006), which enables them to adapt more to the environment of a foreign market. Moreover, the older firms were found to have a higher likelihood to survive (Evans, 1987). Nevertheless, the older companies that are inclined to participate in GPN only occurs in the case of SMEs. One plausible reason for older SMEs' inclination to participate may be attributed to the fact that SMEs have several limitations: limited information about the overseas market and a lower level of capital. Dong and Men (2014) found that younger firms deal with severe financing obstacles while Fatoki and Asah (2011) discovered that older SMEs are more likely to be successful in applying for credit from banks which may be caused by a good reputation from maintaining a good record of past loans (Martinelli, 1997).

Bigger size firms are more likely to participate in the GPN. These findings correspond to the hypothesis and previous studies where firm size was found to be positively associated with production network (Arudchelvan \& Wignaraja, 2015; Harvie et al., 2010; Lu et al., 2018; Wignaraja, 2015). However, the results show that adding employees only increases the likelihood of SMEs' participation. Larger SMEs may tend to be more resilient than the smaller one (Evans, 1987) and have easier access to credit (Beck et al., 2005; Fatoki \& Asah, 2011), which increases their ability to be involved in the GPN.

The percentage of a firm owned by foreign parties also affects the firm's participation in the GPN; this is true for both larger firms and SMEs and consistent with the previous studies (Wignaraja, 2015; Harvie et al., 2010). The reason is that the entry of foreign investors may led to technology transfer, as 
suggested by Wignaraja (2015), or information about foreign markets and distribution channels (Aitken, Hanson, \& Harrison, 1997).

Human capital is also an essential factor that influences the probability of the firm's participation in the GPN. This finding is consistent with the hypothesis and the findings of Wignaraja (2015). However, the results show that human capital only affects SMEs. A possible reason is that compared to larger firms that may have more capital, SMEs tend to depend on their workers' capability.

Technological capabilities - the availability of IQC, technology license, and innovation, seem to be the essential factors that determine the firm's participation in the GPN. These findings are consistent with the hypothesis and previous studies where having an IQC (Harvie et al., 2010; Wignaraja, 2015), a technology license (Wignaraja, 2015), and product innovation (Harvie et al., 2010) was found to significantly affect company participation in production networks. A possible explanation is that technological capability may improve production efficiency which enables a firm to increase its export performance (Bhaduri \& Ray, 2007). However, the impact of technological capabilities varies between larger firms and SMEs. IQC and product innovation seems to benefit the larger firms which indicate that large companies may more easily meet the quality standards and improve their products, given the number of resources and technology at their disposal. On the other hand, the technology license factor only affects SMEs' involvement, suggesting that technology license from a foreign company may give more benefits for the smaller firms.

\section{CONCLUSION}

The GPN may provide every country the opportunity to participate in it and expand its economy through value-added creation. However, the GPN comprises complex interactions between companies that are located across several countries; thus, the role of a country's institutions becomes very important. This paper argues that in addition to a firm's characteristics and technological capability, institutions may also affect a firm's participation in the production network. Specifically, this study analyzes the effect of access to credit, import license, and competition from the informal sector. These factors represent the following, respectively: financial institution, trade facilitation, and business environment.

Based on the results, most variables of institutions were found to be statistically significant. Although there are some variations between the larger firms and SMEs, the findings highlight the importance of institutions for a firm's participation in the GPN. First, access to credit is found to be the factor that influences SMEs' participation, indicating that SMEs in Indonesia still perceive access to credit as an obstacle, which hampers their participation. Second, import license seems to be the most crucial factor that affects both the larger companies and SMEs' participation. The findings of this study imply that trade facilitation in terms of providing access to imported materials is necessary to offer more resources and a higher quality of input of production. Moreover, a higher quality of input of production is essential to produce a higher quality of output; this, in turn, may increase the competitiveness of domestic firms (Bhaduri \& Ray, 2004). The last point is that the informal sector seems to affect larger firms more than 
SMEs. This impact may be indirect, as explained by Farell (2004); for example, the taxes for a formal firm may increase if the government has a revenue deficit.

For the firm characteristics, there are also some distinctions between the larger firms and SMEs. First, older SMEs tend to participate in the GPN, which means that older firms may have more advantages than a younger company, for example, in accessing credit due to their reputation. Second, bigger firms or SMEs are more likely to participate in the GPN, suggesting that benefits are associated with firm size. For examples, they can access credit (Beck et al., 2005; Fatoki \& Asah, 2011) or have a higher survival capability (Evans, 1987). For foreign ownership, both the larger firms and SMEs are affected by foreign ownership, implying that the presence of a foreign company may benefit local firms. Another difference between larger firms and SMEs is that the factor of human capital only influences SMEs. A possible reason is that SMEs, unlike larger firms that have more capital, may tend to depend more on labor capability; thus, human capital affects SMEs' participation. Next, technological capability determines firm participation. Specifically, having an IQC and initiating product innovation increases the likelihood of larger firms' participation while having a technology license influence the participation of SMEs. Technological capabilities increase a firm's performances, thereby increasing their likelihood of participating in the GPN.

The findings of this study have certain implications for policies that may be implemented by the government to encourage the participation of local companies in the GPN. First, apart from improving the ability of SMEs to manage financial administration such as bookkeeping, financial development systems in terms of favorably financing SMEs should be provided by financial institutions. To reduce asymmetrical information between SMEs and bank institutions, the government can create signaling policies through bookkeeping training certification or financial statement health certificates. Second, effective and efficient procedures should be established for granting import permits. Simplifying procedures and making them more transparent can be regarded as a form of trade institutional reform that aims to reduce transaction costs and eliminate the possibility of rent-seeking. In addition to a stronger rule of law and a better legal system, implementing a tax for informal firms and providing tax incentives to formal companies may prevent the growth of the informal sector and encourage the informal sector to formalize. However, higher taxes must only be applicable to informal companies that have a certain value of sales and assets.

It should be noted that this study has several limitations. First, this study specifically focuses on Indonesia and, thus, the results of this study may not be applicable to other countries. Second, due to the small number of samples, the results of this study are based on regression conducted for all manufacturing sectors that may have different characteristics; therefore, when implementing the policies suggested in this study, they should be adjusted based on the characteristics of each industrial sector. Therefore, further research needs to specifically analyze some sectors based on very large data samples. 


\section{REFERENCES}

Abonyi, G., \& Van Slyke, D. M. (2010). Governing on the edges: Globalization of production and the challenge to public administration in the twenty-first century. Public Administration Review, 70, s33-s45.

Acemoglu, D., Johnson, S., \& Robinson, J. (2004, May). Institutions as the fundamental cause of long-run growth (NBER Working Paper 10481). Retrieved January 31, 2019, from https://www.nber.org/papers/w10481

Acemoglu, D., \& Johnson, S. (2005). Unbundling institutions. Journal of Political Economy, 113(5), 949-995.

Aitken, B., Hanson, G. H., \& Harrison, A. E. (1997). Spillovers, foreign investment, and export behavior. Journal of International Economics, 43(1-2), 103-132.

Andersson, S., Gabrielsson, J., \& Wictor, I. (2009). International activities in small firms: Examining factors influencing the internationalization and export growth of small firms. Canadian Journal of Administrative Sciences/ Revue Canadienne Des Sciences de l'Administration, 21(1), $22-34$.

Arudchelvan, M., \& Wignaraja, G. (2015, February). SME internationalization through global value chains and free trade agreements: Malaysian evidence (ADBI Working Paper 515). Retrieved June 8, 2018, from https://www.adb.org/sites/default/files/publication/156370/adbiwp515.pdf

Baldauf, A., Cravens, D. W., \& Wagner, U. (2000). Examining determinants of export performance in small open economies. Journal of World Business, 35(1), 61-79.

Baldwin, R. E. (2016). The great convergence: Information technology and the new globalization / Richard Baldwin. Cambridge, Massachusetts: The Belknap Press of Harvard University Press.

Beck, T., Demirgüç-Kunt, A., \& Maksimovic, V. (2005). Financial and legal constraints to growth: Does firm size matter? The Journal of Finance, 60(1), 137-177.

Bewick, V., Cheek, L., \& Ball, J. (2005). Statistics review 14: Logistic regression. Critical Care, 9(1), 112.

Bhaduri, S., \& Ray, A. S. (2004). Exporting through technological capability: Econometric evidence from India's pharmaceutical and electrical/electronics firms. Oxford Development Studies, 32(1), 87-100.

Coad, A., Segarra, A., \& Teruel, M. (2016). Innovation and firm growth: Does firm age play a role? Research Policy, 45(2), 387-400.

D'Angelo, A. (2010). Innovation and export performance: A study of Italian hightech SMEs. Journal of Management \& Governance, 16(3), 393-423.

Damuri, Y. R. (2006, April). An evaluation of the need for selected trade facilitation measures in Indonesia: Implications for the WTO negotiations on trade facilitation (ARTNeT Working Paper Series, No. 10). Retrieved June 4, 2019, from https://www.econstor.eu/handle/10419/178368

Dell'Anno, R. (2009). Institutions and human development in the Latin American informal economy. Constitutional Political Economy, 21(3), 207-230. 
Dick, A. R. (1994). Does import protection act as export promotion? Evidence from the United States. Oxford Economic Papers, 46, 83-101

Distinguin, I., Rugemintwari, C., \& Tacneng, R. (2016). Can informal firms hurt registered SMEs' access to credit? World Development, 84, 18-40.

Dollar, D., \& Kidder, M. (2017) Institutional quality and participation in global value chains. In the World Bank (Ed.), Measuring and analyzing the impact of GVCs on economic development (pp. 161-173). Washington DC: The World Bank.

Dollar, D., \& Kraay, A. (2003). Institutions, trade, and growth. Journal of Monetary Economics, 50, 133-162.

Dong, Y., \& Men, C. (2014). SME financing in emerging markets: Firm characteristics, banking structure and institutions. Emerging Markets Finance and Trade, 50(1), 120-149.

Evans, D. (1987). The relationship between firm growth, size, and age: Estimates for 100 manufacturing industries. The Journal of Industrial Economics, 35(4), 567-581.

Farell, D. (2004). The hidden dangers of the informal economy (The McKinsey Quarterly 3). June 04, 2019, from

https://www.immagic.com/eLibrary/ARCHIVES/GENERAL/MCKNSY US/M040413F.pdf

Fatoki, O., \& Asah, F. (2011). The impact of firm and entrepreneurial characteristics on access to debt finance by SMEs in King Williams' Town, South Africa. International Journal of Business and Management, 6(8), 170-179.

Friedman, E., Johnson, S., Kaufmann, D., \& Zoido-Lobaton, P. (2000). Dodging the grabbing hand: The determinants of unofficial activity in 69 countries. Journal of Public Economics, 76(3), 459-493.

Goedhuys, M., \& Sleuwaegen, L. (2013). The impact of international standards certification on the performance of firms in less developed countries. World Development, 47, 87-101.

Goksel, T. (2012). Financial constraints and international trade patterns. Economic Modelling, 29(6), 2222-2225.

Haltiwanger, J. C., Lane, J. I., \& Spletzer, J. R. (1999). Productivity Differences Across Employers: The roles of employer size, age, and human capital. American Economic Review, 89(2), 94-98.

Harvie, C., Narjoko, D., \& Oum, S. (2010, October). Firm characteristic determinants of SME participation in production networks (ERIA Discussion Paper Series 2010-11). Retrieved May 6, 2018, from http://www.eria.org/ERIA-DP-2010-11.pdf

Javalgi, R. G., White, D. S., \& Lee, O. (2000). Firm characteristics influencing export propensity. Journal of Business Research, 47(3), 217-228.

Johnson, S., Kaufmann, D., \& Zoido-Lobatón, P. (1998). Regulatory discretion and the unofficial economy. The American Economic Review, 88(2), 387-392.

Jones, R.W. \& Kierzkowski, H. (1988). The role of services in production and international trade: A theoretical framework. The Political Economy of International Trade, 31-48. 
Krueger, A. O. (1990). Government failures in development. Journal of Economic Perspectives, 4(3), 9-23.

Levchenko, A. (2007). Institutional quality and international trade. Review of Economic Studies, 74, 791-819.

Lu, Y., Shi, H., Luo, W., \& Liu, B. (2018). Productivity, financial constraints, and firms' global value chain participation: Evidence from China. Economic Modelling, 73, 184-194.

Machmud, Z., \& Huda, A. (2011). SMEs' access to finance: An Indonesia case study. In Harvie, C., S. Oum, \& D. Narjoko (Eds.), Small and medium enterprises (SMEs) access to finance in selected East Asian economies (ERIA Research Project Report 2010-14, pp. 261-290). Retrieved June 4, 2019, from

http://www.eria.org/uploads/media/Research-Project-

Report/RPR_FY2010_14_Chapter_9.pdf

Majocchi, A., Bacchiocchi, E., \& Mayrhofer, U. (2005). Firm size, business experience and export intensity in SMEs: A longitudinal approach to complex relationships. International Business Review, 14(6), 719-738.

Manova, K. (2012). Credit constraints, heterogeneous firms, and international trade. The Review of Economic Studies, 80(2), 711-744.

Martinelli, C. (1997). Small firms, borrowing constraints, and reputation. Journal of Economic Behavior \& Organization, 33(1), 91-105.

Méon, P.-G., \& Sekkat, K. (2008). Institutional quality and trade: Which institutions? Which trade? Economic Inquiry, 46(2), 227-240.

Melitz, M. J. (2003). The impact of trade on intra-industry reallocations and aggregate industry productivity. Econometrica, 71(6), 1695-1725.

Mendi, P., \& Costamagna, R. (2017). Managing innovation under competitive pressure from informal producers. Technological Forecasting and Social Change, 114, 192-202.

Minetti, R., \& Zhu, S. C. (2011). Credit constraints and firm export: Microeconomic evidence from Italy. Journal of International Economics, 83(2), 109-125.

Muûls, M., \& Pisu, M. (2009). Imports and exports at the level of the firm: Evidence from Belgium. World Economy, 32(5), 692-734.

North, D. C. (1991). Institutions. Journal of Economic Perspectives, 5(1), 97-112.

OECD. (n.d). Dataset: Trade in value-added (TiVA): Principal indicators. Retrieved May 23, 2019, from https://stats.oecd.org/Index.aspx?DataSetCode=TIVA_2018_C4\#

Pérez, J. A. H., Kunc, M. H., Durst, S., Flores, A., \& Geldes, C. (2018). Impact of competition from unregistered firms on R\&D investment by industrial sectors in emerging economies. Technological Forecasting and Social Change, 133, 179-189.

Pla-Barber, J., \& Alegre, J. (2007). Analysing the link between export intensity, innovation and firm size in a science-based industry. International Business Review, 16(3), 275-293.

Prete, D., D., Giovannetti, G., \& Marvasi, E. (2018). Global value chains: New evidence for North Africa. International Economics, 153, 42-54.

Rasiah, R., M., Roesli., P., \& Sanjivee. (2010, March). The significance of production networks in productivity, exports and technological 
upgrading: Small and medium enterprises in electric-electronics, textilegarments, automotives and wood products in Malaysia (ERIA Research Project Report 2010-8). Retrieved June 8, 2018, from http://www.eria.org/uploads/media/Research-ProjectReport/RPR_FY2009_08_Chapter_9.pdf

Sapienza, H. J., Autio, E., George, G., \& Zahra, S. A. (2006). A capabilities perspective on the effects of early internationalization on firm survival and growth. Academy of Management Review, 31(4), 914-933.

Singh, D. A. (2009). Export performance of emerging market firms. International Business Review, 18(4), 321-330.

The World Bank (2012). Doing business in a more transparent world. Washington DC: The World Bank.

The World Bank (2013). Doing business 2013 smarter regulations for small- and medium-sized enterprises. Washington DC: The World Bank.

The World Bank (2014). Doing business 2014 understanding regulations for small-and medium-sized enterprises. Washington DC: The World Bank.

The World Bank (2015). Doing business 2015 going beyond efficiency. Washington DC: The World Bank.

The World Bank (2016). Doing business 2016 measuring regulatory quality and efficiency. Washington DC: The World Bank.

The World Bank (2015). Enterprise Surveys. Retrieved April 20, 2018, from http://www.enterprisesurveys.org

Wagner, J. (2001). A note on the firm size-Export relationship. Small Business Economics, 17, 229-237.

Wakelin, K. (1998). Innovation and export behaviour at the firm level. Research Policy, 26, 829-841.

Wignaraja. (2015). Factors affecting entry into supply chain trade: An analysis of firms in Southeast Asia. Asia and the Pacific Policy Studies, 2(3), 623642.

Van Dijk, M. (2002, February). The determinants of export performance in developing countries: The case of Indonesian manufacturing (Eindhoven Centre for Innovation Studies Working Paper 02.01). Retrieved May 27, 2019, from https://www.researchgate.net/profile/Michiel_Van_Dijk/publication/486 8933_The_Determinants_of_Export_Performance_in_Developing_Coun tries_The_Case_of_Indonesian_Manufacturing/links/02e7e52b2d1582d3 13000000.pdf 